\title{
Performance, carcass quality and organ characteristics of broiler finishers fed rumen epithelial scrappings meal (RESM) as replacement for fish meal
}

\author{
Philip Cheriose Nzien Alikwe ${ }^{1}$, Elijah Ige Ohimain ${ }^{2,}$, , Festus Ayodeji Sunday Dairo ${ }^{3}$ \\ ${ }^{1}$ Nutritional Biochemistry Research Unit, Animal Science Department, Niger Delta University, Bayelsa State, Nigeria \\ ${ }^{2}$ Veterinary Microbiology Research Unit, Biological Sciences Department, Niger Delta University, Bayelsa State, Nigeria \\ ${ }^{3}$ Animal Science Department, Ekiti State University Ado Ekiti, Ekiti State, Nigeria
}

\section{Email address:}

eohimain@yahoo.com (E. I. Ohimain)

\section{To cite this article:}

Philip Cheriose Nzien Alikwe, Elijah Ige Ohimain, Festus Ayodeji Sunday Dairo. Performance, Carcass Quality and Organ Characteristics of Broiler Finishers Fed Rumen Epithelial Scrappings Meal (RESM) as Replacement for Fish Meal. American Journal of Life Sciences. Vol. 2, No. 1, 2014, pp. 29-34. doi: 10.11648/j.ajls.20140201.14

\begin{abstract}
A 56-day feeding trial involving 105 day old Anak broilers was carried out in a completely randomized design to evaluate, the performance, carcass yield and organ characteristics of broilers fed rumen epithelial scrapping meal (RESM a byproduct of cattle rumen processing that constitutes an environmental pollutant within the abattoir) at dietary levels of $0,25,5075$ and $100 \%$. Results show that the feed efficiency of 50,75 and $100 \%$ RESM were superior to the control and $25 \%$ inclusion at the starter phase but at the finisher phase the control was superior over the other treatments and the average final weight gain of the control at the finisher phase was superior $(\mathrm{P}<0.05)$ over all other treatments though all the birds attained a weight of over $2 \mathrm{~kg}$ at the end of the 56 day trial. The dressing $\%$ and eviscerated $\%$ of $100 \%$ RESM was superior to all other treatments though not $(\mathrm{P}>0.05)$ significantly different, while the eviscerated weight $(\mathrm{kg})$ of $25 \%$ RESM was superior to all other treatments. The internal organs (\% Eviscerated Weight -EW) were all similar except for the heart where the control was significant $(\mathrm{P}<0.05)$ over all other treatments while in the cut up parts $(\% \mathrm{EW})$ there was no significant difference $(\mathrm{P}>0.05)$ among the parts such as wing, head, drum stick, thigh weight, breast weight, except the back weight where the control, $25 \%$, and $50 \%$ show significant difference $(\mathrm{P}<0.05)$ over the other treatments, though the control and $50 \%$ showed similarity to 75 and $100 \%$ treatment levels. Overall, no particular trend emerged indicating that RESM could be used to replace fishmeal without any adverse effect both to the birds and the final consumers since it is consumed in some parts of the country.
\end{abstract}

Keywords: Performance, Epithelial Scrapings, Carcass Yield, Internal Organs, Broilers

\section{Introduction}

Feed represents the largest single item of cost in intensive poultry production all over the world. The high cost of poultry feed has also caused serious animal protein deficiency among Nigerians especially among low income earners, leading to malnutrition. Poultry products offer considerable potentials to bridge the animal protein intake gap for the fact that poultry grows faster, mature earlier and has greater affordability, easy to rear and absence of taboos to production and consumption than other species of livestock. Several animal nutritionists involved in feed formulation for monogastrics animals have utilized agro industrial by-products regarded as non-conventional feed sources because they are abundantly produced (Fetuga and Tewe, 1985). The ever-increasing cost of livestock feeds with the attendant increase in the cost of animal products such as meat, eggs and milk shows that there is the need to explore the use of nonconventional feed ingredients in the feeding of domestic animals (Alawa and Umunna, 1993; Ani and Omeje, 2007; Owen, et al, 2009). Apart from the major conventional animal protein sources (Fishmeal, Meat meal, Blood meal) for instance, others like Maggot meal, Shrimp waste meal, Silkworm meal, Poultry offal meal, Feather meal, Crab meal, Grasshopper meal (Akpodiete et.al 1997, Fanimo et.al 1998, Khatun et al, 2003, Ojewola and Udom, 2005, Ojewola and Annah, 2006) have been tried as alternative protein sources for broilers. Efficient 
utilization of meat by-products is important for profitability of meat industry. It has been estimated that $11.4 \%$ of the gross income from beef and $7.5 \%$ of the income from pork comes from the by-products (Liu, 2009). The nonconventional feed ingredient being considered in this study is Rumen Epithelial Scrapping Meal (RESM) obtained from slauthering of cattle in the various abattoirs all over the Nigeria. Its use in monogastric livestock feeding as a source of animal protein has not been fully exploited. Alikwe et al (2013) recently documented the microbial load of RESM. Therefore, the goal of the current study, was to evaluate the performance, carcass quality and organ characteristics of broiler finisher birds fed RESM as replacement for fishmeal.

\section{Materials and Methods}

\subsection{Experimental Procedure}

\subsubsection{Collection and Processing of Experimental Materials}

Rumen epithelial scraping was collected at the Bodija abattoir at Ibadan during rumen offal processing, sun-dried for about $8 \mathrm{hr}$ daily for 4 days until they become crispy. The sun-dried scrappings were milled in a hammer mill and sieved and then proximate analysis (AOAC, 1990) of samples were done before incorporating them into the experimental diets.

\subsubsection{Chemical Analysis}

The samples of the experimental diets were analyzed for their proximate contents by AOAC(1990) methods. Gross energy was determined using a Gallenkamp bomb calorimeter while the amino acids were determined using amino acid analyzer model 80-2107-07 Auto Loader. The formulated diets were also analyzed by the same procedures to determine their chemical composition. The chemical composition of the RESM and the amino acid content is presented in Table $1 \mathrm{a}$ and $1 \mathrm{~b}$.

Table 1a. Proximate composition (g/100g) and Gross Energy (kcal/g).

\begin{tabular}{cccccc}
\hline $\begin{array}{c}\text { Dry } \\
\text { Matter, \% }\end{array}$ & $\begin{array}{c}\text { Crude } \\
\text { Protein, \% }\end{array}$ & $\begin{array}{c}\text { Ether } \\
\text { extract, \% }\end{array}$ & Ash, \% & $\begin{array}{c}\text { Crude } \\
\text { Fibre, \% }\end{array}$ & $\begin{array}{c}\text { Nitrogen } \\
\text { Free Extract, \% }\end{array}$ \\
\hline $89.52 \pm 0.01$ & $53.00 \pm 0.35$ & $5.08 \pm 0.02$ & $15.98 \pm 0.01$ & $2.33 \pm 0.01$ & $13.13 \pm 0.34$ \\
\hline
\end{tabular}

Table 1b. Amino acid content of Rumen Epithelial Scrapping Meal (RESM) (means, $n=2), m g / g$.

\begin{tabular}{cccc}
\hline Lysine & $\mathbf{0 . 8 7} \pm \mathbf{0 . 0 2}$ & Leucine & 7.89 $\pm \mathbf{0 . 0 3}$ \\
\hline Methionine & $1.36 \pm 0.01$ & Tryptophan & $3.03 \pm 0.02$ \\
Threonine & $28.47 \pm 0.04$ & Alanine & $0.52 \pm 0.02$ \\
Aspartic acid & $7.54 \pm 0.01$ & Glycine & $4.38 \pm 0.02$ \\
Glutamine & $10.52 \pm 0.02$ & Arginine & $1.67 \pm 0.03$ \\
Serine & $3.28 \pm 0.01$ & Valine & $23.81 \pm 0.04$ \\
Tyrosine & $25.51 \pm 0.03$ & Proline & $0.58 \pm 0.00$ \\
Cysteine & $3.50 \pm 0.01$ & Phenyl alanine & $25.53 \pm 0.01$ \\
Histidine & $24.34 \pm 0.01$ & & \\
\hline
\end{tabular}

\subsubsection{Formulation of Experimental Diets and Management of the Broilers}

The feed ingredients used in ration formulation were purchased locally. The RESM was sourced as earlier discussed. The results of the proximate and Amino acid compositions earlier determined (Table $1 \mathrm{a}$ and $1 \mathrm{~b}$ ) were used as guides in the manual ration formulation of the five experimental diets. The experimental diets were prepared and adequately mixed in the mixer. All diets were compounded to contain identical crude protein content (isonitrogenous) and gross energy (isocaloric). Diet $\mathrm{T}_{\mathrm{I}}$ was the control diet formulated without the inclusion of RESM. Diets T2, T3, T4, and T5 were formulated such that RESM was incorporated at $25 \%, 50 \%, 75 \%$, and $100 \%$ respectively. All diets were also supplemented with feed grade methionine and lysine. The formulated diets are shown in Tables 2 and 3.

Table 2. Gross Composition of Experimental Diets Fed to Broiler. Starters Chicks (0-4 Weeks)

\begin{tabular}{|c|c|c|c|c|c|}
\hline INGREDIENTS \% & T1 & $\mathbf{T 2}$ & T3 & T4 & T5 \\
\hline Maize & 55.00 & 55.00 & 55.00 & 55.00 & 55.00 \\
\hline Full fat soya & 23.00 & 23.00 & 23.00 & 23.00 & 23.00 \\
\hline Fishmeal & 5.700 & 4.275 & 2.850 & 1.425 & 0.000 \\
\hline Rumen Epithelial Scrappings Meal & 0.000 & 1.425 & 2.850 & 4.275 & 5.700 \\
\hline Blood meal & 4.50 & 4.50 & 4.50 & 4.50 & 4.50 \\
\hline Maize offal & 5.00 & 5.00 & 5.00 & 5.00 & 5.00 \\
\hline Bone meal & 3.00 & 3.00 & 3.00 & 3.00 & 3.00 \\
\hline Oyster shell & 1.50 & 1.50 & 1.50 & 1.50 & 1.50 \\
\hline Sodium Chloride & 0.70 & 0.70 & 0.70 & 0.70 & 0.70 \\
\hline
\end{tabular}




\begin{tabular}{cccccc}
\hline INGREDIENTS \% & T1 & T2 & T3 & T4 & T5 \\
\hline Vitamin mineral premix* & 1.00 & 1.00 & 1.00 & 1.00 & 1.00 \\
Methionine & 0.30 & 0.30 & 0.30 & 0.30 & 0.30 \\
Lysine & 0.30 & 0.30 & 0.30 & 0.30 & 0.30 \\
Total & 100.00 & 100.00 & 100.00 & 100.00 & 100.00 \\
Calculated values & & & & & \\
ME (Kcal/g) & 2.82 & 2.79 & 2.77 & 2.75 & 2.73 \\
Crude protein & 23.10 & 23.25 & 23.31 & 23.30 & 23.24 \\
Calorie: Protein ratio & 122.07 & 120.00 & 118.83 & 118.03 & 117.45 \\
Determined Chemical composition & & & & & \\
Dry matter & 92.80 & 92.75 & 91.70 & 92.61 & 91.73 \\
Crude protein & 23.35 & 22.87 & 21.70 & 21.23 & 21.06 \\
Ether extract & 3.55 & 3.43 & 3.63 & 3.75 & 3.34 \\
Crude fibre & 4.97 & 4.99 & 4.71 & 4.89 & 4.87 \\
Ash & 7.14 & 6.71 & 6.37 & 6.81 & 5.21 \\
Nitrogen Free Extract & 53.90 & 54.75 & 58.42 & 55.93 & 55.25 \\
\hline
\end{tabular}

*Vitamin/mineral premix provided the following vitamin and minerals per $\mathrm{kg}$ of diet:A, 10,000 I.U.; $\mathrm{D}_{3}, 300$ I.U.;

E. 8.0 I.U.; K, 2.0mg; $\mathrm{B}_{1}, 2.0 \mathrm{mg} ; \mathrm{B}_{6}, 1.2 \mathrm{mg} ; \mathrm{B}_{12}, 0.12 \mathrm{mg}$; Nianin 1.0mg; Panthothenic acid, 7.0mg; Folic acid, 0.6mg;

Cholic, 500mg; C, 10.0mg; Fe, 60mg; Mn, 80mg; Mg, 100mg; Cu, 8.0mg; Zn, 50mg; Co, 0.45mg; I, 2.0mg and Se, 0.1mg.ANUPCO, Anglican Nutrition Products Company, England

Table 3. Composition Of Experimental Diet Fed To Finishers (g/100g).

\begin{tabular}{|c|c|c|c|c|c|}
\hline Ingredients (\%) & $\mathbf{T 1}$ & T2 & T3 & T4 & T5 \\
\hline Maize & 56.00 & 56.00 & 56.00 & 56.00 & 56.00 \\
\hline Fullfat Soybean & 24.00 & 24.00 & 24.00 & 24.00 & 24.00 \\
\hline Fish meal & 4.500 & 3.375 & 2.250 & 1.125 & 0.000 \\
\hline Rumen Epithelial Scrapping Meal & 0.000 & 1.125 & 2.250 & 3.375 & 4.500 \\
\hline Blood meal & 3.003 .00 & 3.00 & 3.00 & 3.00 & 3.00 \\
\hline Maize offal & 5.20 & 5.20 & 5.20 & 5.20 & 5.20 \\
\hline Bone meal & 3.20 & 3.20 & 3.20 & 3.20 & 3.20 \\
\hline Oyster shell & 1.50 & 1.50 & 1.50 & 1.50 & 1.50 \\
\hline Sodium chloride & 0.30 & 0.30 & 0.30 & 0.30 & 0.30 \\
\hline Vitamin mineral premix* & 0.30 & 0.30 & 0.30 & 0.30 & 0.30 \\
\hline Methionine & 1.00 & 1.00 & 1.00 & 1.00 & 1.00 \\
\hline Lysine & 1.00 & 1.00 & 1.00 & 1.00 & 1.00 \\
\hline Total & 100.00 & 100.00 & 100.00 & 100.00 & 100.00 \\
\hline \multicolumn{6}{|l|}{ Calculated values } \\
\hline Crude protein & 21.37 & 21.21 & 20.18 & 19.20 & 18.13 \\
\hline $\operatorname{ME}(\mathrm{Kcal} / \mathrm{g})$ & 2.31 & 2.32 & 2.33 & 2.33 & 2.32 \\
\hline Calorie: Protein ratio & 122.07 & 120.00 & 118.83 & 118.03 & 117.45 \\
\hline \multicolumn{6}{|l|}{ Determined chemical composition } \\
\hline Dry matter & 92.80 & 92.75 & 91.70 & 92.61 & 91.73 \\
\hline Crude protein & 23.35 & 22.87 & 21.70 & 21.23 & 21.06 \\
\hline Ether extract & 3.55 & 3.43 & 3.63 & 3.75 & 3.34 \\
\hline Crude fibre & 4.97 & 4.99 & 4.71 & 4.89 & 4.87 \\
\hline Ash & 7.14 & 6.71 & 6.37 & 6.81 & 7.21 \\
\hline Nitrogen Free extract & 53.90 & 54.75 & 58.42 & 55.93 & 55.25 \\
\hline
\end{tabular}

*Vitamin/mineral premix provided the following vitamin and minerals per kg of diet: A, 10,000 I.U.; D3, 300 I.U.; E. 8.0 I.U.; K, 2.0mg; B1, 2.0mg; B6, 1.2mg; B12, 0.12mg; Nianin 1.0mg; Panthothenic acid, 7.0mg; Folic acid, 0.6mg; Cholic, 500mg; C, 10.0mg; Fe, 60mg; Mn, 80mg; Mg, 100mg; Cu, $8.0 \mathrm{mg} ; \mathrm{Zn}, 50 \mathrm{mg}$; Co, $0.45 \mathrm{mg}$; I, 2.0mg and Se, $0.1 \mathrm{mg}$. ANUPCO, Anglican Nutrition Products Company, England

\subsubsection{Broiler Birds Husbandry and Experimental Design}

A total of 105 day-old broiler chicks of the Anak heavy strain were purchased from Zartech hatchery, a division of Zartech Farms, Ibadan, Oyo-State, Nigeria. All chicks were electrically brooded on a deep litter floor at the University of Ibadan Teaching and Research Farms. They were fed a $24 \%$ crude protein broiler starter commercial ration ad libitum for the first 3 days after arrival from the hatchery prior to the commencement of the experiment. Water was also provided ad libitum with appropriate antibiotics and anti stress particularly after arrival. The chicks were vaccinated against Newcastle disease, infectious bursal disease and fowl pox while sulphanamide drug was given in water against coccidiosis. The experimental birds were divided into five treatment groups of 21 birds per group. Each treatment group was further replicated three times 
consisting of 7 birds per replicate. The groups were then randomly allotted to the 5 dietary treatments in a Completely Randomized Design (CRD). Feed and water were offered ad libitum and data on feed intake, weight gain, live weight, and mortality were recorded weekly. The experiment lasted for 56 days.

\subsubsection{Carcass Yield Evaluation}

On the $57^{\text {th }}$ day of the trial, 2 birds ( 1 male and 1 female) per replicate group were randomly selected for carcass and organ weight evaluation after fasting them over night but not without water. The birds were weighed, slaughtered by severing the jugular vein and allowed to bleed thoroughly according to the method recommended by Odunsi et al (1999). Birds were scalded at $75^{\circ} \mathrm{C}$ in a water bath for about 30 seconds before defeathering and then the birds were reweighed to calculate feathers weight by difference. The dressed chicks were later eviscerated. The wings were removed by cutting anteriorly severing at the humeoscapular joint, the cuts were made through the rib head to the shoulder girdle, the back was removed intact by pulling anteriorly. Thighs and drum stick were dissected from each carcass and weighed separately. The measurement of the carcass traits (dressed weight \%, eviscerated weight \%, thigh, drumstick, shank, chest, back, neck, wing, belly fat and head) were taken before dissecting out the organs. All the carcass traits except the dressed and eviscerated weight were expressed as percentages of the live weight while the organs were expressed in $\mathrm{g} / \mathrm{kg}$ body weight.

\subsection{Statistical Analysis}

Data were subjected to the analysis of variance (Steel. and Torrie. 1980)) to determine the significant variation in the various parameters analyzed while the means were separated by the Duncan's multiple range test (Duncan, 1955). The experimental layout followed the completely randomized design. Data were analysed using SPSS version 17 (SPSS Inc., Chicago).

\section{Results and Discussion}

The results of proximate composition, gross energy and amino acids content are presented in Table $1 \mathrm{a}$ and $1 \mathrm{~b}$ while the feed composition is presented in Table 2. The Rumen Epithelial Scrappings meal (RESM) was relatively high in crude protein at $53.00 \pm 0.35 \%$; and amino acid. About $75 \%$ of the total nitrogen in most feedstuff of animal origin is protein-nitrogen although this proportion varies with animal species (Olomu, 2010). The protein level and amino acids composition of RESM clearly give it a rating in the category of other conventional protein sources especially of animal origins (Olomu, 2010). Comparing RESM with other protein sources of animal origin, which are known for their nutritive values as rations in feeds, RESM is rich in the sulphur hydroxyl imino, aromatic, acidic and basic amino acid. It is low in lysine when compared to hen's egg, cow's milk, fishmeal and larvae meal (Eka, 1987; Orr et.al, 1966, Oluokun, 2000) though can easily be supplemented with blood meal. The ash (mineral) $15.98 \pm 0.01 \%$ content was remarkably high.

The results of the performance characteristics for starter average body weight gain at the end of the starter phase (128d) were significantly different $(\mathrm{P}<0.05) \quad$ The general trend observed for this parameter in the starter phase tended towards increased live weight gain with increased levels of dietary RESM replacement of fish meal up to $100 \%$ in starter phase. Results of the feed intake in the starters depicted an increase with increasing level of RESM up to $75 \%$ (Table 4) but fell as fishmeal (FM) was completely withdrawn in the starter phase. At the starter phase, birds on $100 \%$ RESM and $0 \%$ FM with the least feed intake had the highest body weight gain though statistically similar to those on $75 \% \mathrm{RESM} / 25 \% \mathrm{FM}$ but different from $\mathrm{T} 1$ and T3 with $0 \%$ RESM/100\%FM and $50 \%$ RESM $/ 50 \%$ FM respectively which were similar in weight gains.

Table 4. Performance Characteristics of Broiler Chicks (Starter) Fed Rumen Epithelial Scrapping Meal as replacement for fish meal.

\begin{tabular}{|c|c|c|c|c|c|c|}
\hline Parameters & T1 & $\mathbf{T 2}$ & T3 & T4 & T5 & SEM \\
\hline Average initial weight (g/bird) & 184.35 & 164.40 & 172.80 & 178.80 & 169.5 & \\
\hline Average final weight (g/bird) & 1024.45 & 1063.40 & 1042.70 & 1175.10 & 1145.00 & \\
\hline Average body weight gain (g/bird) & $840.10^{c}$ & $898.60^{\mathrm{b}}$ & $869.90^{\mathrm{c}}$ & $996.30^{\mathrm{a}}$ & $975.50^{\mathrm{a}}$ & 6.24 \\
\hline Total feed intake $(\mathrm{g} / \mathrm{bird})$ & 1174.05 & $1181 . .05$ & 1183.35 & 1194..05 & 1135.70 & 16.55 \\
\hline Feed efficiency & $0.72^{\mathrm{b}}$ & $0.76^{\mathrm{b}}$ & $0.74^{\mathrm{b}}$ & $0.84^{\mathrm{a}}$ & $0.86^{\mathrm{a}}$ & 16.55 \\
\hline
\end{tabular}

abc: means on the same row with any identical superscript are not significant $(\mathrm{P}>0.05)$.

The treatment effects (Table 5) on feed intake were significant $(\mathrm{P}<0.05)$. Feed consumption was highest for birds on treatment 5 ( $4349.40 \mathrm{~g} / \mathrm{bird})$ followed by those fed diet T2, (4286.00 g/bird) while the lowest feed intake was recorded for those on control diet $\mathrm{T} 1$. The results of the performance characteristics for birds are shown in Table 5. Treatment effects on the average weight gain were significant $(\mathrm{P}<0.05)$ birds on control diet was the best followed by birds on $\mathrm{T} 2$, while birds on $\mathrm{T} 3$ and $\mathrm{T} 4$ were similar, though all the treatments attained an average final weight of over $2000 \mathrm{~g}$ within 56 days. There were significant differences $(\mathrm{P}<0.05)$ in the feed utilization efficiency among birds in T1, T2 and while birds in T4 and T5 were similar. The general trend observed for this parameter in the birds was that as RESM increases up to $100 \%$ it tended towards decreased live weight gain i.e. average final weight gain decreased as RESM increased. Treatment E $(100 \%)$ had the highest feed intake but the least final live weight gain. 
Table 5. Performance characteristics of broiler finishers (5-8 weeks) fed Rumen epithelial Scrappings Meal as replacement for fish meal.

\begin{tabular}{|c|c|c|c|c|c|c|}
\hline Parameters & T1 & T2 & T3 & T4 & T5 & SEM \\
\hline Average feed intake (g/bird) & $4001.95^{\mathrm{d}}$ & $4286.00^{b}$ & $4222.40^{\mathrm{c}}$ & $4192.80^{\mathrm{c}}$ & $4349.40^{\mathrm{a}}$ & 8.42 \\
\hline Average initial weight (g/bird) & 1024.45 & 1063.00 & 1042.70 & 1175.10 & 1145.00 & \\
\hline Average final weight (g/bird) & 2401.40 & 2363.00 & 2190.40 & 2105.10 & 2045.00 & \\
\hline Average final wt gain (g/bird) & $1376.95^{\mathrm{a}}$ & $1237.00^{\mathrm{b}}$ & $1147.7^{\mathrm{c}}$ & $930.00^{\mathrm{d}}$ & $900.00^{\mathrm{d}}$ & 12.38 \\
\hline Feed conversion ratio & 2.91 & 3.46 & 3.68 & 4.51 & 4.83 & \\
\hline Feed efficiency & $0.340^{\mathrm{a}}$ & $0.290^{\mathrm{b}}$ & $0271^{\mathrm{b}}$ & $0.220^{\mathrm{c}}$ & $0.205^{\mathrm{c}}$ & 0.01 \\
\hline Mortality & - & - & - & - & - & - \\
\hline
\end{tabular}

$\mathrm{abc}=$ means on the same row with any identical superscript are not significant $(\mathrm{P}>0.05)$

Except for the liver, all other organs measured were statistically different $(\mathrm{P}<0.05)$. The results of the carcass measurements and organ weights of broiler chicken fed RESM and slaughtered at 56 days of age are shown in Table 6. All the parameters measured among the treatment groups showed similarity $(\mathrm{P}>0.05)$. Live weight value of birds in the control was superior to all others though not significant. Birds with 75\% RESM had the least live and eviscerated weight. The dressed weight indicated similar values for treatments T2, T3 and T4. The highest nonsignificant dressed weight was obtained from treatment $\mathrm{T} 2$ while the least was treatment $\mathrm{T} 4$. The eviscerated weights of treatments 5, 2, 3 and 1 are similar. Treatment 4 had highest wing, drum stick and thigh weights while treatment 2 had the highest gizzard, lung, head, back and breast weight. In all no particular trend could be observed.

Table 6. Carcass and Organs Characteristics of Experimental Birds (0-8 weeks finishers) fed Rumen Epithelial Scrapping Meal as replacement for fish meal.

\begin{tabular}{|c|c|c|c|c|c|}
\hline Parameters & T1 & $\mathbf{T 2}$ & T3 & T4 & T5 \\
\hline Live weight (kg) & 2.401 & 2.363 & 2.190 & 2.105 & 2.045 \\
\hline Dressing \% & 73.50 & 80.62 & 81.38 & 81.87 & 84.41 \\
\hline Dressed weight (kg) & 1.753 & 1.905 & 1.782 & 1.723 & 1.730 \\
\hline Eviscerated \% & 67.88 & 74.81 & 75.81 & 69.62 & 75.45 \\
\hline Eviscerated weight (kg) & 1.630 & 1.768 & 1.660 & 1.470 & 1.543 \\
\hline \multicolumn{6}{|l|}{ Internal organs $(\% \mathrm{EW})$} \\
\hline Liver & 1.86 & 2.10 & 2.18 & 1.76 & 1.59 \\
\hline Heart & $1.04^{\mathrm{a}}$ & $0.76^{\mathrm{ab}}$ & $0.61^{b}$ & $0.47^{\mathrm{b}}$ & $0.56^{\mathrm{b}}$ \\
\hline Gizzard & $2.03^{c}$ & $3.23^{\mathrm{a}}$ & $2.22^{\mathrm{b}}$ & $3.20^{\mathrm{a}}$ & $2.19^{\mathrm{b}}$ \\
\hline Lung & $0.69^{\mathrm{ab}}$ & $0.72^{\mathrm{a}}$ & $0.56^{\mathrm{bc}}$ & $0.55^{\mathrm{bc}}$ & $0.49^{\mathrm{c}}$ \\
\hline \multicolumn{6}{|l|}{ Cut up parts $(\% \mathrm{EW})$} \\
\hline Wing & 10.33 & 10.65 & 11.46 & 11.50 & 9.97 \\
\hline Head & 2.73 & 3.07 & 2.52 & 2.78 & 2.11 \\
\hline Drum stick & 20.69 & 20.69 & 26.54 & 28.48 & 24.51 \\
\hline Back weight & $15.87^{\mathrm{ab}}$ & $20.17^{\mathrm{a}}$ & $17.18^{\mathrm{ab}}$ & $15.75^{\mathrm{b}}$ & $16.17^{\mathrm{b}}$ \\
\hline Thigh weight & 12.55 & 13.03 & 14.13 & 15.00 & 11.56 \\
\hline Breast weight & 20.08 & 30.03 & 29.99 & 29.40 & 29.80 \\
\hline
\end{tabular}

abcd: means on the same row with any identical superscript are not significant $(\mathrm{P}>0.5)$

In this study there was no particular trend in the eviscerated percentage but varied from $67.88 \%$ (T1) to $75.81 \%$ (T3). Various values have been reported varying from $70.08-75.3 \%$ as percentage of liveweight, (Onwudike 1980b). The result obtained in this study is in agreement with Broadbent et al (1981), who got $69 \%$ and Atuahene et al (1987) who got a value range of $68.02-$ 70.60 but higher than what Njoku (1986) obtained (64.93 to $64.04 \%$ ). Variations in the values reported could be attributed to dietary or genetic factors, age or weight at slaughter and processing methods. Dressed percentage of 73.50 to 84.41 as obtained in this study was in line with Akpodiete et al (1997) who obtained dressed \% of 77.33 to 83.00, but higher than those obtained by Hayse and
Morrison (1978). Many researchers have reported gross morphological changes in the organs of birds fed diets containing various feed ingredients. In addition, the age and weight of the bird at slaughter have also influenced the weight of organs. In this study organ weight at 8 weeks varied as follows: Liver (1.59-2.18) Heart (0.47-1.04), Gizzard (2.03-3.23), Lungs (0.49-0.72) g/100g of the eviscerated weight which is in agreement with Broadbent et al (1981) who reported organs weights of broilers at 8 weeks of age and fed normal diet as follows: Gizzard (1.301.5), heart (0.72-0.74), liver (2.89-3.54) at $\mathrm{g} / \mathrm{kg}$ of eviscerated carcass. 


\section{Conclusion}

The replacement of fish meal with RESM in broiler chicken starter and grower finisher diet resulted in higher weight gain as compared to control diets. The general trend observed for this parameter in the birds was that as RESM increases up to $100 \%$ it tended towards decreased live weight gain i.e. average final weight gain decreased as RESM increased. Treatment E (100\%) had the highest feed intake but the least final live weight gain.

Carcass yield was comparable for birds fed with control diets and those containing RESM. From the technical point of view, the substitution was a success. Under commercial conditions, using RESM could also be justified by a reduction in cost of feeding broiler chicken to market weight. However, it is advisable that RESM should be analyzed for microbial content and its effects before it could be widely used for broiler chicken feeding.

\section{References}

[1] Alikwe, P. C. N., Ojo, S.K.S and Ohimain, E. I. 2013 Effects of processed rumen epithelial scrapings meal (RESM) based diet on gastro microbial load of broiler finishers. Nigerian Journal of Agriculture, Food and Environment. 9 (2): 26 - 31

[2] AOAC (1990) Official methods of analysis. $15^{\text {th }}$ Edition Association of Official Analytical Chemists, Washington DC

[3] Akpodiete O.J., Ologbobo A.D. and Ayoade O.G. (1997) Replacement of Maggot Meal for Fish Meal in Broiler Chicken Diets. In: Livestock Products (Eds.) Ologbobo, A.B., Iyayi, E.A., Adesehinna A.K. and Bamgbose A.M. 6476.

[4] Alawa, J.P. and N.N. Umunna (1993). Alternative feed formulation in the developing countries: prospects for utilization of agro industrial by-products. Journal of Animal Production Research. 13 (2): 63 - 68

[5] Ani, A.O. and Omeje, O.D. (2007). Effect of enzyme supplementation of raw Bambara groundnut waste diet on nutrient utilization of broiler finisher. Proceedings 33rd Ann. Conf.Nigerian Society for Animal Production (NSAP), Ogun - Nigeria pp $424-426$

[6] Atuahene, C.C., Donkoh, A. and Swatson, H. (1987) Oil palm slurry as a partial replacement for maize in the diets of broiler chickens. Anim. Feed Sci. Technol. 17:157-162

[7] Broadbent, L.A., Wilson, B.J. and Fisher C. (1981) The composition of the broiler chicken at 56 days of age, outpu8t, components and chemical composition. Br. Poult. Sci. 22:385-390.

[8] Duncan, D. B. (1955) Multiple range and multiple F-tests. Biometrics 11:1-42.

[9] Eka, O..(1987) Evaluation of nutritive value of feed for growing broilers in Northern Nigeria, Nig. J. of Science. 21: $52-54$.
[10] Fanimo, A.O, Oduguwa, O.O, Jimoh, T.O and Faronbi, A.O (1998) Performance and Carcass evaluation of broiler chicks fed Shrimp waste meal supplemented with synthetic amino acid. Nig. J.Prod. , 25: 17-21

[11] Fetuga, B.L, O.O. Tewe (1985) Potential of agro industrial by products and crop residues as livestock feed compounds. Nig. Fd. J. 2(2) 136-142.

[12] Hayse P. L. and Marrison W. M. (1984) Eviscerated Yield of Component Parts and Meat, Skin and Ratio in Broiler Chick. Poultry Sci. 57:718-722.

[13] Khatun, R, Howlider, M.A.R., Rahman, M.M., and Hassanuzzaman, M., (2003) Replacement of Fishmeal by silkworm in broiler diets. Pak J.Biol. Sc., 6: 6955-6958

[14] Liu, D.C. (2009). Better Utilization of By-Products from the meat industry. Department of Animal Science. National Chung-Hising University Taichung Taiwan Roc.www.agnet.org/library/teb/515/eb/515.pdf Retrieved: $24 / 05 / 2011$

[15] Njoku P.C. (1986) Effect of dietary ascorbic acid supplementation on the performance of broiler chickens in a tropical environment. Anim Feed Sci. Technol. 16: 17-24

[16] Odunsi. A.A, Farinu, G.O., Akinola, J.O and Togun, V.A (1999) Growth, Carcass characteristics and body composition of broilers fed wild sunflower (Tithonia diversifolia) forage meal . Trop Anim Prod Invest 2: 205211

[17] Ojewola G.S and Udom, S.F, (2005), Chemical evaluation of the nutrient composition of some unconventional animal protein sources, Int'1 J. Poult. Sci., 4 (10): 747-745

[18] Ojewola, G.S and Annah,, S.I. (2006) Nutritive and Economic value of Danish fishmeal, crayfish dust meal, and Shrimp waste meal inclusion in broiler diets. Int'l J. Poult. Sci., 5(4): 390-394

[19] Olomu J .M (2011) Monogastric animal nutrition: Principles and practice. Jackson Publishing, Benin City, Nigeria Pp478

[20] Oluokun, J.A (2000) Upgrading the nutritive value of full fat soyabean meal for broiler production with either Fishmeal or black soldier fly larvae meal (Hermetia illucens) Trop J. Anim Sci. 3(2) : 51-61

[21] Onwudike, O.C. (1986b) Palm kernel meal as feed for poultry 2. Diets containing palm kernel meal for starter and grower pullets. Ani. Feed Sci. \& Tech. 1, 16: 187-194

[22] Orr M. L Watt, BK (1966) Amino acid content of foods. Home Economics, Research report No 4, USDA (US Govt. Printing Office.) Washington D.C

[23] Owen, O.J., A.O. Amakiri, E.U. David, V.N. Nyeche and L. Ndor (2009). Proximate composition, energy content and mineral profile of Vernonia amygdalina (Bitter Leaf) meal. Proc. 14th Ann. Conf. Animal Science Association of Nigeria $(A S A N), 14$ th $-17^{\text {th }}$ September, Ogbomoso, Oyo State. Pp $173-176$.

[24] Steel, R.G.D. and Torri J.H. (1980) Principles and Procedures of Statisics, McGraw Hill, NY 137-169. 